\title{
$\bullet$ Ethics and Narratives: An Analysis of Commercials of Patanjali Ayurveda
}

\author{
IJCRR \\ Section: Healthcare \\ ISI Impact Factor \\ (2019-20): 1.628 \\ IC Value (2019): 90.81 \\ $\operatorname{SJIF}(2020)=7.893$

\section{Aleem Khan ${ }^{1}$, Subhash Kumar ${ }^{2}$}

'Research Scholar, Department of Journalism and Mass Communication, Manipal University Jaipur, Rajasthan, India; ${ }^{2}$ Associate Professor,

Department of]ournalism \& Mass Communication, Manipal University Jaipur, Rajasthan, lndia.

\section{ABSTRACT}

Introduction: Advertising is used as an effective tool to promote various products and ideas in the desired economic goals. In contemporary time digital media has been used as a powerful medium, it has the potential of reaching millions of consumer. In such conditions, advertisers have influenced society through embedded content such as dialogues, text and visual narratives. These Deceptive practices in advertising have created challenges for regulatory bodies. Although the Advertising Standard Council of India (ASCI,1985) were formulated various codes of conduct to control misleading advertisements. In this paper, commercials of Patanjali Ayurveda, an Indian consumer goods company that has reached new heights in the international market has been studied.

Objectives: This study aims to analyse the narratives of TV commercials of Patanjali products, to examine the ASCI codes and ethics in advertisements of Patanjali and the audience perception about the Patanjali advertisements.

Methods: Keeping the study objectives in view, the authors adopted a narrative analysis method for examining the content of selected advertainments. The questionnaire was administered through a google form. A random sample from the target audience group was selected for the study.

Results: A total of one hundred and eighteen respondents responded to the survey. In which $44 \%$ and $49 \%$ of respondent feel that Patanjali has used patriotic and cultural themes for promoting their products. $51 \%$ of respondent feel that boycotting the other products is not justified and $21 \%$ of respondents think that linking patriotism in the marketing of goods is beneficial, $45 \%$ of respondents believe that it is not justified. The majority of respondent believes that promoting negative sentiments in advertising practices is not good for the country's social fabric and economic goals.

Conclusion: The study has found that the cosmetic and dairy products ads had included misleading content in the narratives; the emotions of patriotism and faith have been used for the economic benefit of Patanjali by using a national icon, symbols and false claims in their advertisements. They appreciated social stereotypes and unfairly targeted competitive MNCs through the ads narratives. it promotes unfair competition in the market. Also, some advertisements of the Patanjali products has violated the $\mathrm{ASCl}$ codes and fined for harmful and misleading content by the regulatory bodies. Although such ads were banned for airing on television, all these ads continue to exist on digital media under the name of Patanjali Ayurveda and ASCI is failed to ban such ads on Digital media platforms.

Key Words: Patanjali, Advertising, Content, ASCI, Ethics, Agenda

\section{INTRODUCTION}

The Oxford dictionary explains advertisement as a public announcement of goods to promote sales and the primary objective of advertising is to sell something through persuasion. Today, these commercials have become an important social and economic force in the world. ${ }^{1}$ After globalization advertising industry has expanded in a very progressive manner and has kept pace with the growth of multinational companies in India. It has a far-reaching influence on the social, cultural and moral values of the society. ${ }^{2}$ It has come across innumerable images, audios, text for various products. The excessive use of various forms of media for the promotion of Goods and services cannot be ignored in our day to day lives. Advertisements affect our life to a large extent and it is necessary to develop an understanding of the effective relationship between

Corresponding Author:

M Aleem Khan, PhD Scholar, Department of Journalism and Mass Communication, Manipal University Jaipur, Jaipur. 303007, Rajasthan, India. Email: aleem.letters@gmail.com

ISSN: 2231-2196 (Print) ISSN: 0975-5241 (Online)

Received: $21.03 .2020 \quad$ Revised: 23.04 .2020

Accepted: 15.05 .2020

Published: 25.04 .2021 
promotional messages and consumers, be would undertake some social responsibility in the sending messages. ${ }^{3}$ Goldman has opined that advertising as a major social and economic institution, strives to maintain cultural hegemony by providing us with socially constructed ways of seeing about the world. According to Ewen and Ewen, "advertising not only sells us the product or services but it also indirectly tells us ways, to understand the world". ${ }^{4}$

There are numerous instances where advertisements have mislead with hidden propaganda and false claims through TV and digital media platforms. So, the government has established professional organization like ASCI (The Advertising Standards Council of India) as a non-statutory tribunal, as its executive aim is to receive complaints about misleading advertisements and create a self-regulatory mechanism of ensuring ethical advertising practices for the industry". 5 It exercises the influence in motivating advertisers to selfregulate by observing honesty and truthfulness in the content and fair promotional practices among advertisers. ${ }^{6}$

In this context, Patanjali Ayurveda "a leading herbal and ayurvedic product manufacturer has been included in the top three advertisers in television until 2017. In the same year, Patanjali significantly ramped up its online presence, it has created advertising narratives in regional language for different states.' The channel name 'Patanjali Ayurveda' on YouTube which is started in July 2014 has more than 96.000 subscribers and reached 3 million views in the first month of 2017; and after collaboration with Google, it has climbed to 15 crore views. It also started an online campaign for boycotting foreign products with the "Go swadeshi (indigenous) movement". Acharya Balkrishna CEO of Patanjali Ayurveda told 'The print' in an interview that "the company had consciously reduced its TV ads and plane to give more focus on digital media and we are planning to increase more spends on digital media in some months". ${ }^{8}$

The ASCI guidelines have been overlooked many times by the Patanjali Ayurveda Ltd. In December 2016 it was fined Rs 11 lakhs for "misbranding and putting up misleading advertisements" of their products in the District Court of Haridwar, Uttarakhand, India. The products were found to be in "violation of Section 52 (misbranding) and Section 53 (misleading advertisement) of Food Security norms and section 23.1 (5) of Food Safety and Standard (packaging and labelling) Regulation". 9 The researcher like Morden found that the basic function of "Television commercial is to create awareness about the goods and services so that viewers of the advertisement can take the rational decision from their mind. ${ }^{10}$ Advertising is always a subject of monitoring because healthy and fair practices among the companies are the primary objective of ASCI (Advertising council of India). ${ }^{2}$

The book "Advertising and sales promotion" explain the typical form of untruths in the advertisements which have exag- gerated facts, misinterpretation, false claim, unfair comparison etc. she states that today the numbers of unethical and obscene advertisements are increasing instead of decreasing, the government is not in favour to regulate advertisements by his enforcement. ${ }^{11}$

Hence, the study has tried to analyse the commercials of Patanjali Ayurveda.

- To review the commercials of Patanjali product.

- To analyse the narratives of cosmetic, dairy product advertisements.

- To examine the violations of ethics in the advertisement of Patanjali products.

The questions for this study as follows

- Did Patanjali advertisements use misleading content?

- Is there any agenda in advertising content?

- Did Patanjali commercials follow the advertising ethics?

The Bogdan Nichfor States that "Advertising is a tool of mass communication and Its content and performed functions are not yet defined in generally recognized theory". ${ }^{13}$ So, the study, deal with Affective response theory which focuses on the emotional response that advertising content can generate. It refers, "consumers and their preferences are based on pleasure, feelings and emotions which arise from exposure to the message, the objective characteristics of the product playing a less important role in this direction". ${ }^{14}$ The Agenda-setting theory of McCombs and Donald Shaw opined that "media sets the agenda for the masses. This theory suggested that media do not tell people 'what to think', but they may tell people "what to think about. ${ }^{15}$

\section{MATERIALS AND METHODS}

The research work is analytical. It has used primary as well as secondary data for analysis. A close-ended questioner was administered through a Google form, A random sample method used for primary data collection from the target audiences to get viewers insight on commercials, that is provide a quantitative description of the Patanjali Ads pattern. In Qualitative nature, research was used narrative analysis technique as Coulter and Barone to understand the Pattern of Patanjali advertisements. ${ }^{16,17}$ Suitable multivariate techniques were used for data analysis.

The secondary data for the research is largely based on information that is already available and accessible from television, web media, news, articles, blogs etc. Advertisements that have been used for content analysis are selected from the official website of Patanjali Ayurveda and YouTube channel.

- In the qualitative procedure, Patanjali advertisements were selected by purposeful sampling to analyse and 
understand the advertisement content (text, language, images, narration).

- In the quantitative technique, a study has chosen 120 students as a sample size (Male and Female). The random sample is used for the collection of 120 responses of undergraduate students from Manipal University Jaipur and a close-ended questionnaire was used for data collection. $98 \%$ of respondents come from the 18 to 24 years of age group. The questionnaire was administered through a Google form. A total of 119 students were responded to the survey.

\section{Data analysis and Interpretation}

\section{A. Judiciary and Regulatory Proceedings against Patan- jali Advertisement}

In Sep 2017 Delhi High court stopped the airing of Patanjali's 'Chyawanprash' ads when competitor brand Dabur accused that the commercial of Patanjali disparaged his product. ${ }^{18}$ Former Minister of State for Information and Broadcasting Rajyavardhan Rathore told the Lok Sabha in a written reply that "the government has received 33 complaints from April 2015 to July 2016 against Patanjali ads. ${ }^{19}$ As per the findings of the consumer complaints council (CCCI), ASCI and the department of consumer affairs has informed the Legislation assembly that 25 out of 33 complained against Patanjali advertisement were considered to violation of Advertising Standards Council of India codes". ${ }^{12,19}$

\section{B. Distribution of Patanjali Ads}

A report of the Broadcast Audience Research Council $(\text { BARC })^{20}$ mentioned that Patanjali Ayurveda had stepped its advertising promotion, and became among one of the top three brands (2017).

\section{Top 5 Genres where Patanjali Adverised} the most in 2017

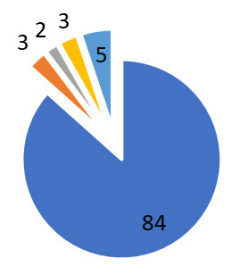

- News Channels " Movies | Business news " Kids | GEC

Figure 1: Distribution of Patanjali Ads (Source: BARC India, 2017).

\begin{tabular}{lc}
\multicolumn{2}{c}{ Distribution of Advertisements } \\
News Channel & $84.4 \%$ \\
Entertainment Channel & $5.45 \%$ \\
Movies Channel & $3 \cdot 35$ \\
Kids Channel & $3.35 \%$. \\
Business News & $2.45 \%$ \\
\hline
\end{tabular}

In the BARC report (Broadcast Audience research council provides reports on TV audience measurement) the total distributions of Patanjali Ads on the News Channel are 84 $\%$. Figure (1) Indicate the total distribution of Patanjali advertainments on different media outlets. Thus, Patanjali has used news channels as an effective tool for his Business Marketing.

\section{Interpretation and analysis of Patanjali Adver- tisements -}

\section{Patanjali Beauty Product Advertisement.}

In the below-mentioned figure (2) Patanjali's advertisement for its 'Soundarya skincare product' begins with two sisters, Saundarya and Aishwarya, the narration describes them as, Saundarya ( a girl) "Paramparaon ka Paalan karne wali (follows old traditions and cultures)", Aishwarya (another girl) "badass, wannabe type girl". The ad goes on to establish that Saundarya received more and more compliments while Aishwarya tries more make-up to hide her blemished skin. Young boys and girls praise Saundarya for her beautiful skin while the same group of people ridicule and shame Aishwarya because she is using cosmetics products of another brand. she upset with the acne on her face. due to the state of her skin, college mates make poke fun at her beauty.

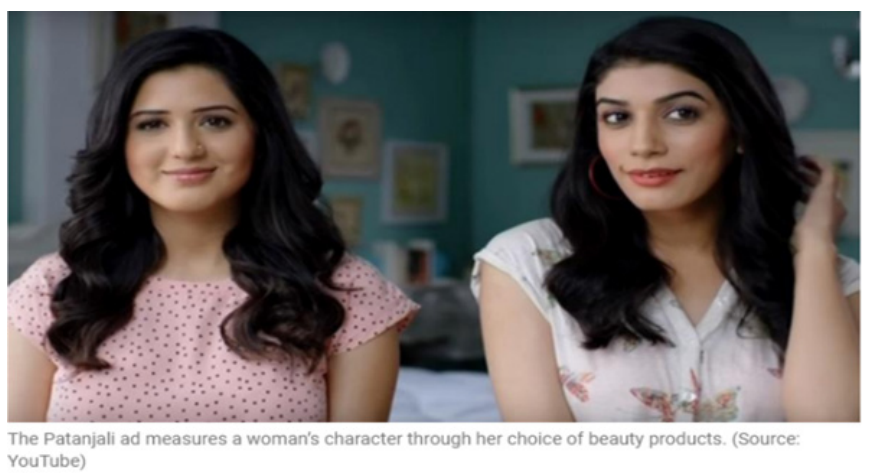

Figure 2: Patanjali Soundarya line products Advertisement (Source- YouTube). ${ }^{21}$

The words 'bindass and wannabe type girl', "which is usually a colloquial Hindi term for 'carefree', as something negative, shades of sexiest, this advertisement not only mocks women but also implies that being 'carefree and cool' is bad". ${ }^{22}$ The advertisement is centred on its regressive nature, the ad claims that people seem to look down upon women who are not traditional and didn't use Patanjali product are 'wannabe type or uncultured girl'. These ads broadcast at a time when other brands across the market are making attempts to create progressive ads that break gender and racial stereotypes. While these ads have portrayed girls using Patanjali product 
as modest, beautiful and have cultured values whereas other girls who have not used this Patanjali product are 'carefree', 'immodest' and 'uncultured'. This ad promotes moral policing and insulting the woman's freedom of choice. The narrative, visuals of the ad are violating the ASCI codes.

\section{The Advertisement for Patanjali 'Dant Kanti Tooth- paste'.}

In the above figure (3) Patanjali 'Dant Kanti' toothpaste ads, the advertiser claims that India is suffering from foreign enemies who are establishing their businesses or investing in our country and extracting money from our country. Furthermore, the advertisement appeals, "Just like crores of "Deshbhakt" (Patriotic) Indians, shopkeepers and customers in the country who are aware of this foreign economic atrocity should give priority to Patanjali's products in their shops to contribute in the service of the country, using Patanjali products will help in fulfilling the dreams of Mahatma Gandhi, Bhagat Singh etc. Opposite to this, the promoter of Patanjali claims that profits earned from the sale of products are accrued in the account of any person. However, the CEO of Patanjali Ayurveda limited Balkrishna owns 94 per cent of the shares of Patanjali Ayurveda Limited. Forbes magazine listed Balkrishna as India's 25th richest individuals in 2018-19. As the advertisement states that people should use Patanjali products like 'other Deshbhakts (patriots)'. It raises a question mark on the nationalism of every Indian citizen as if, who do not use Patanjali products, are the supporters of Britishers. Its means they exploiting patriotic sentiments of the masses by advisements for sheer profit. This ad is a clear violation of the ASCI code because it leads to unfair and unethical competition in the market.

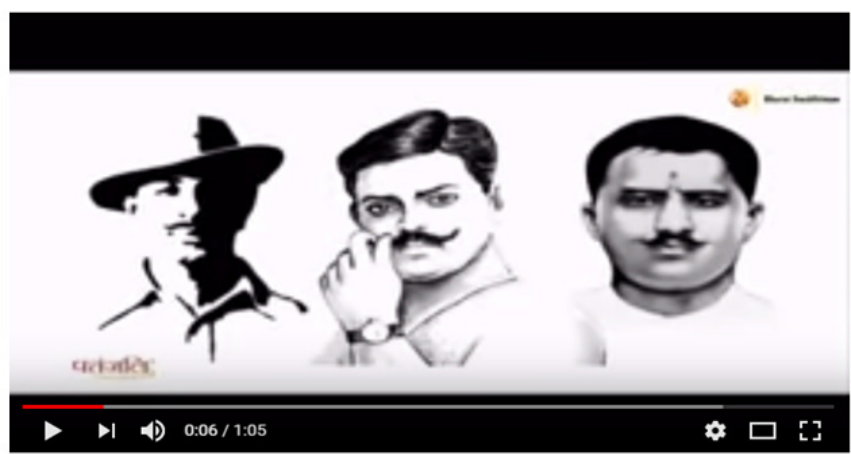

Patanjali Ad Misuses The Cross To Portray Christians As Outsiders \& Enemies!

Figure 3: Dant Kanti Freedom Ad (Source- YouTube).

\section{Patanjali Ad on 'Independence Day'.}

This ad (Figure 4) recreates a scene from pre-independence India with a black-white clip depicting the Swadeshi move- ment on Boycott of foreign products by our freedom fighters for Independence The ads suddenly zoom to India's map where three crosses projecting out in three directions and between the crosses the words E, I and Co. It depicted the East India Company which subsequently paved the way for British colonial rule in India. During the visuals narrator of the ad baba Ramdev starting his appeal (Which have a false claim and misleading content), "Videshi companiya hamare desh ke liye bahut hi khatarnak hain kyunki desh ka dhan desh ke bahar lekar ja rahi hain or desh me koi bhi bada kaam charity ka nhi karti hain, in sabka vikalp hai Patanjali ka satvik swadeshi abhiyan' (Translation: Foreign brands are very dangerous for our country because they are exporting our own mony to abroad and even they are not doing any charity in the country, using of Patanjali product are the only solution for the problem); they narrate, 'Patanjali ka profit kisi vyakti vishesh ke liye nahi balki charity ke liye hai, Aaj Azadi ke 71 saal baad bhi China, US, UK jaisi companiyan loot kar rahi hain'.

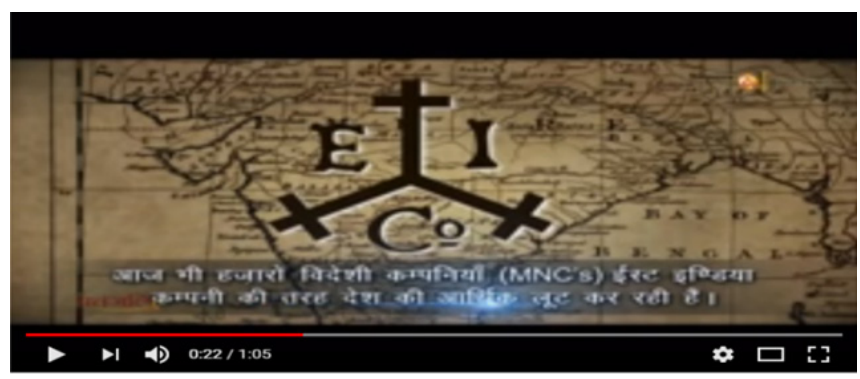

Patanjali Ad Misuses The Cross To Portray Christians As Outsiders \& Enemies!

Figure 4: Patanjali Independence Day Advertisement ${ }^{1}$ (Source- YouTube)

The Patanjali brand has been aggressively portrayed its indigenous identity and pitching multinational companies as "thieves" in their ads. Patanjali has compared its global rivals to the East India Company and portrayed MNCs as a symbol of colonisation and oppression of Britishers. He appealed to achieve complete freedom or "swaraj" from them. The advertisement states that MNCs are the same way, as "East India Company enslaved and looted us, multinational companies are still doing the same by selling soap, shampoo, toothpaste, cream, powder and similar daily items at an exorbitant price". Patanjali doing his business for charity purposes without making any profit. When this ad was aired on TV, the Christian community protested against Patanjali for uses religious symbols like the Cross in their ad and portray Christians as outsiders. ${ }^{23}$ This type of commercial elements degrades other cultures and provoke sentiments to spread hatred in the majority of people against minorities. This kind of ads has affected the morale and the secular fabric of India.

1Celebrate This Independence Day with Patanjali Products (2016). Retrieved from https://www.youtube.com/watch?v=Lh2GLVba3 CU 


\section{Patanjali 'Cow Ghee' Ads.}

In the below-mentioned Advertisement (figure- 5) Baba Ramdev explicates some of the facts regarding cow and their sacredness and benefits i.e. Population, ghee production and consumption.

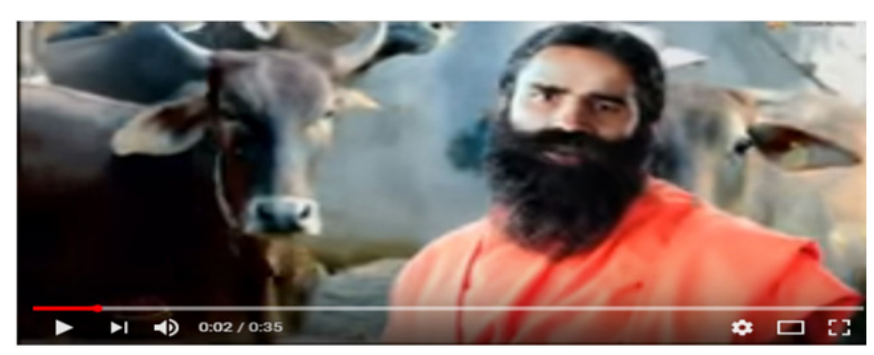

Patanjali Cows Ghee I Product by Patanjali Ayurveda

Figure 5: Patanjali Cows Ghee | Product by Patanjali Ayurveda (Source- YouTube).

The voice-over adds, "Nirantar ho Rahi Goukashi (cow slaughter) Ke Karan Kuch Log Sochte hen Ki Itne bade Paimane par Ghee Kaise Tayyar ho rha hai? Desh me 12 crore Gai haain. Translation of VO is (Due to continuous slaughtering of cow peoples thinks how they are being produced Ghee at such a large scale because there is only 102 million cow in India). Another Patanjali Ad emphasises, "Patanjali Ghee Apnaye, Gou Mata ko Katal Khano me Jaane se Bachayein (use Patanjali Ghee and stop the holy cow from slaughtering"). Through the narrative of the advertisement, Baba Ramdev is spreading propaganda about cow slaughtering and facts related to the cow population. Whereas the Government statics' official data about the cow population according to the National Dairy Development Board (2012) census is 267.6 Million (Approx.: 26.7600000 crores. $^{24}$ This ad targets a particular community that are involved in the Cattle business. now India is suffering from a 'Mob lynching' kind of attacks. It also coerces the viewers to use and purchase Patanjali ghee to save the 'Holy cow' from other communities. it is a direct violation of ASCI codes.

\section{QUESTIONNAIRE RESULTS}

A close-ended questionnaire was used for the data collection through the Google form.

\section{Demographic characteristics of respondents}

All respondents (120) were students pursuing graduation in journalism at Manipal University Jaipur. The data indicate the pattern of Patanjali advertisement, preferences of both consumer and advertiser. It also presents the audience perception of the Patanjali advertisements.
Table 1: Questionnaire results

\begin{tabular}{|c|c|c|c|c|}
\hline $\begin{array}{l}\text { S. } \\
\text { No. }\end{array}$ & Question & Options & Responses & Percentage \\
\hline \multirow[t]{2}{*}{1.} & \multirow{2}{*}{$\begin{array}{l}\text { Do you like } \\
\text { watching Adver- } \\
\text { tisement? }\end{array}$} & Yes & 68.1 & 68.1 \\
\hline & & No & 31.9 & 31.9 \\
\hline \multirow[t]{4}{*}{2.} & \multirow{4}{*}{$\begin{array}{l}\text { Which Source } \\
\text { do you generally } \\
\text { access for Adver- } \\
\text { tisement? }\end{array}$} & Print & 21 & 17.6 \\
\hline & & $\mathrm{TV}$ & 89 & 74.8 \\
\hline & & Radio & 15 & 12.6 \\
\hline & & Web & 69 & 58 \\
\hline \multirow[t]{4}{*}{3.} & \multirow{4}{*}{$\begin{array}{l}\text { Generally, in } \\
\text { which medium } \\
\text { do you see Pa- } \\
\text { tanjali Advertise- } \\
\text { ment }\end{array}$} & Print & 37 & 31.1 \\
\hline & & $\mathrm{TV}$ & 102 & 85.7 \\
\hline & & Radio & 8 & 6.7 \\
\hline & & Web & 21 & 17.6 \\
\hline \multirow[t]{4}{*}{4.} & \multirow{4}{*}{$\begin{array}{l}\text { During which } \\
\text { Program have } \\
\text { you watched } \\
\text { Advertisement } \\
\text { of Patanjali Prod- } \\
\text { uct? }\end{array}$} & Daily shop & 43 & 36.1 \\
\hline & & $\begin{array}{l}\text { News Bul- } \\
\text { letin }\end{array}$ & 55 & 46.2 \\
\hline & & $\begin{array}{l}\text { Sponsored } \\
\text { program }\end{array}$ & 26 & 21.8 \\
\hline & & $\begin{array}{l}\text { Entertain- } \\
\text { ment }\end{array}$ & 49 & 41.2 \\
\hline \multirow[t]{4}{*}{5.} & \multirow{4}{*}{$\begin{array}{l}\text { What basic dif- } \\
\text { ferences do you } \\
\text { feel between } \\
\text { Advertisements } \\
\text { of Patanjali Prod- } \\
\text { uct and another } \\
\text { brand? }\end{array}$} & Sentimental & 22 & 18.6 \\
\hline & & Patriotic & 53 & 44.9 \\
\hline & & Religious & 28 & 23.7 \\
\hline & & Cultural & 58 & 49.2 \\
\hline \multirow[t]{4}{*}{6.} & \multirow{4}{*}{$\begin{array}{l}\text { Do you think that } \\
\text { Promoting nega- } \\
\text { tive sentiments } \\
\text { by criticizing } \\
\text { and boycotting } \\
\text { foreign product } \\
\text { through Patanjali } \\
\text { Advertisement is } \\
\text { justified? }\end{array}$} & Yes & 18 & $15 \cdot 3$ \\
\hline & & No & 61 & 51.7 \\
\hline & & Can't say & 37 & 31.4 \\
\hline & & Don't Know & 10 & 8.5 \\
\hline \multirow[t]{4}{*}{7.} & \multirow{4}{*}{$\begin{array}{l}\text { Do you think } \\
\text { that linking Pat- } \\
\text { riotism through } \\
\text { advertisement of } \\
\text { Patanjali product } \\
\text { is Justified? }\end{array}$} & Yes & 25 & 21.2 \\
\hline & & No & 53 & 44.9 \\
\hline & & Can't say & 25 & 21.2 \\
\hline & & Don’t Know & 19 & 16.1 \\
\hline
\end{tabular}

\section{RESULTS}

The respondents like to watch an advertisement for information regarding product and services (Table-1). Most of the respondents' access TV and web media to watch advertisements, Patanjali advertisements most seen on the TV during news bulletins, according to respondents Patanjali advertisements based on patriotic pattern and cultural themes, Majority of respondents believe that linking patriotism with the 
advertisement is not justified. Its influences consumer behaviour towards products and create unfair competition with other brands. India has relaxed its FDI (Forging Direct Investment) norms to allow $100 \%$ investment in the trading of food products made in India, ${ }^{25}$ free trade doesn't come with disadvantages, like potentially giving enough power to international companies to influence our domestic policies in favour of their business. So, questioning the credibility of MNC's (Multinational Companies) is not justified. The narrative text of the Patanjali Ayurveda advertisement has taken his multinational competitors like vultures or 'lootera' (thieves) by comparing them to the East India Company. ${ }^{26}$ Though it is not good for the PM's policies such as 'Make In India' and the Indian economy. It is also noted that Patanjali advertisements have spread wrong facts and misleading narratives in Patanjali Ghee, Dant Kanti and Cosmetic Ads.

\section{CONCLUSION}

The study concluded the consumers are accessing TV followed by web media for getting information regarding the company goods. Advertisers have used digital media as a substance for adding content that is banned or subject to violation. The viewers think that Patanjali advertisements link patriotic and religious sentiments with promotional content is not good practice. Patanjali's multitude of TV commercials aired during news bulletin gives plenty of scopes to spread the message. The narratives in dairy and cosmetic Ads design as agenda-setting, It obliquely spread messages with misleading information and objectional content. The sanctified emotions of patriotism and faith are exploited in Patanjali ads by using false claims, national icons, symbols. This type of ads content has the potential to influence public behaviour from a negative perspective and promote animosity among different communities. As mentioned by the ASCI, Patanjali ads have violated the ASCI codes. Patanjali ads fined by the court for harmful and misleading content and banned on television, but all ads that exist in the digital media platform of Patanjali Ayurveda and ASCI is failed to stop such ads on digital media platforms. They also tried to establish a different kind of economic system of their interest. Through advertising, Patanjali Ayurveda tried to tell peoples what to think about other brands, what to think about someone's nationality, what to think about cultures, what to think about women, what to think about Patriotic values with the promotion of consumers goods.

\section{ACKNOWLEDGMENT}

The Authors acknowledge the immense contribution of respondents from the Department of Journalism and Mass Communication, Manipal University Jaipur. The authors are grateful to authors/ editors/ publisher/ advertisers of all those advertisements, articles, journals, news portals and books from where the literature for this study has been reviewed and discussed in this manuscript.

Ethical clearance: Not applicable.

\section{Source of funding: Self.}

Conflict of Interest: Not applicable.

\section{Authors Contribution:}

Aleem Khan: The first and correspondent author for this research paper has contributed to the conception and design of the work, data collection, writing the analysis and interpretation of the data. Worked on the manuscript during the review process. Both authors discussed the result and commented on the conclusion of the manuscript.

Dr Subhash Kumar: The co-author of this article helped in critical revision, the shape of the manuscript and the conclusion.

\section{REFERENCES}

1. Kaptan. Advertising Regulations, Swarup \& Sons, 2003; 18-35.

2. Kaptan. Social Dimensions of Advertising. Swarup \& Sons. 2003; 93.

3. Goldman, R. Reading Ads Socially. Routledge. London. 1992.

4. Ewen, S \& Ewen, E. Channels of desire: Mass images and the shaping of American consciousness. Minneapolis: University of Minnesota Press, 1992.

5. Advertising council of India. ASCI codes. Viewed on September 2019. Retrieved from https://ascionline.org/index.php/ascicodes.html

6. Gupta O. Advertising in India: Trends and Impact. Gyan Publishing House, 2005:Pg 50-59.

7. Ohri R. Baba Ramdev's Patanjali teams up with Facebook, Google for online advertisement push. 2017, Aug 3. Viewed on October 2019 Retrieved from https://economictimes.indiatimes.com/ industry/cons-products/fmcg/baba-ramdevs-patanjali-teamsup-with-facebook-google-for-online-advertisement-push/articleshow/59889332.cms?utm_source $=$ contentofinterest\&utm medium $=$ text\&utm_campaign $=$ cppst.

8. Chandna H. Why Baba Ramdev's Patanjali ads have gone missing from your TV. 2017, October 29, Viewed on September 2019. Retrieved from https://theprint.in/economy/why-baba-ramdevspatanjali-ads-have-gone-missing-from-your-tv/140962/.

9. Indian Express. Ramdev's Patanjali fined Rs 11 lakh for putting up misleading advertisements. Viewed on September 2019. Retrieved from https://indianexpress.com/article/india/ramdevspatanjali-fined-rs-11-lakh-for-putting-up-misleading-advertisements-4427776/.

10. Morden AR. Elements of Marketing. DP Publication Ltd, London. 1991: Pg14-24.

11. Bootwala S, Lawrence MD, Mali SR. Advertising and sales promotion. Nirali Prakashan, Pune. 2007.

12. Dubbudu R. 25 out of 33 Patanjali ads found violating ASCI Code. Viewed on September 2019. Retrieved from https://factly. in/25-33-patanjali-ads-found-violating-asci-code/.

13. Bogdan\&Nichifor. Theoretical Framework Of Advertising Some Insights. 2014. Retrieved from www.researchgate.net. DOI: $10.29358 /$ sceco.v0i19.260 
14. Holbrook, M. B, Hirschman, E. C. The experiential aspects of consumption: Consumer fantasies, feelings, and fun. JCR. 1982 (9): 132-140.

15. McCombs ME, Shaw DL, Weaver DH. Communication and democracy: Exploring the intellectual frontiers in agenda-setting theory. Mahwah, NJ: Lawrence Erlbaum Associates, 1997.

16. Coulter, A, Cathy. Finding the Narrative in Narrative Research. ER. AERA. 2009. Viewed on September 2019. Retrieved from https://www.jstor.org/stable/25592176.

17. BaroneT. Comments on Coulter and Smith: Narrative Researchers as Witnesses of Injustice and Agents of Social Change?. ER. Sage Publication. 2009. Viewed on September 2019. Retrieved from https://doi.org/10.3102/0013189X09353203,

18. Delhi High Court. Delhi High Court stops Patanjali from airing Chyawanprash ads after Dabur complains. Viewed on September 2019. Retrieved from https://www.businesstoday.in/current/ corporate/delhi-high-court-patanjali-chyawanprash-tv-ads-advertisement-dabur/story/259919.html.

19. Economic Times. 25 Patanjali ads found violating advertising code. Viewed on September 2019. Retrieved from https://retail. economictimes.indiatimes.com/news/food-entertainment/personal-care-pet-supplies-liquor/25-patanjali-ads-found-violating-advertising-code/53460522 .

20. BARC report. 2017. TV Audience Measurement. Retrieved from www.barcindia.co.in
21. Times Now. Baba Ramdev's Patanjali to Sue ASCI. Viewed on September 2019. Retrieved from https://www.youtube.com/ watch? $=\mathrm{V} 0 \mathrm{j}$ joXax9U.

22. Indian express. Patanjali's latest cosmetics ad is all shades of sexist, and cringeworthy. Viewed on September 2019. Retrieved from https://indianexpress.com/article/trending/voice/patanjalisaundarya-latest-ad-sexist-is-all-shades-of-sexist-and-cringeworthy-4520709/.

23. Anand K. Christians Are Angry with Baba Ramdev for 'Misusing' the Cross in a Patanjali Ad. 2017, Aug 15. Viewed on September 2019. Retrieved from http://www.indialivetoday. com/a-patanjali-advertisement-showing-the-cross-as-representing-foreign-products-have-christians-upset/20284.html.

24. Cow Statics. National Dairy Development Board. Viewed on September 2019. Source: www.nddb.coop,

25. PTI. The government allows $100 \%$ FDI in trading of food products. Viewed on September 2019. Retrieved from economictimes.indiatimes.com.

26. PTI. Patanjali products popularity causes discomfort among int' rivals. Viewed on 23 July 2019. Retrieved from https://www. theweek.in/wire-updates/business/2019/07/23/nrg37-ukd-patanjali.html. 